\title{
Results of the Feasibility of Material and Media Aspects of Teaching Books on Sports Nutrition
}

\author{
Luthfie Lufthansa ${ }^{1, a^{\star}}$, Afif Rusdiawan ${ }^{1, b}$, Alfian Yahya ${ }^{1, c}$, Paulus Rah Adi Pawitraa, , and Reno Siska Sari ${ }^{1, e}$ \\ 1Department of Physical Education and Recreation, Faculty of Exact and Sports Science Education, IKIP Budi Utomo, Malang, 65119, Indonesia \\ adabluthfie@gmail.com; brusdiawan.a@gmail.com; c alfianyahya23@gmail.com; d super_paitro@yahoo.com; ${ }^{e}$ renosiska87@gmail.com \\ ${ }^{*}$ Corresponding Author \\ Whatsapp number: [085790760080]
}

How to Cite : Lufthansa, L., Rusdiawan, A., Yahya, A., Pawitra, P., R., A., Sari, R., S. (2019). Results of the Feasibility of Material and Media Aspects of Teaching Books on Sports Nutrition. International Journal for Educational and Vocational Studies, 1 (5), 448-450

\section{ARTICLE HISTORY}

Received: 5 June 2019

Revised: 11 July 2019

Accepted: 18 August 2019

KEYWORDS

Textbooks;

Sports;

Nutrition Science;

\section{ABSTRACT}

This study aims to determine the results of the feasibility of the material aspects and media of sports nutrition teaching textbooks. This research is a research on the development of sports nutrition science textbooks. The development of the teaching book on Nutrition Sports Science refers to the 4D model developed by Thiagarajan, et al. (1974) which consists of 4 stages, namely Define, Design, Development, and Disseminate, modified to be adapted to this study. This textbook is tested by material and media experts. The instrument used is an expert validation instrument. Based on the results of the study it can be concluded that the Sports Nutrition Science textbook was declared fit for use as a sports Nutrition Science textbook by material and media experts.

This is an open access article under the CC-BY-SA license.

\section{INTRODUCTION}

The Directorate General of Higher Education (2009) said that textbooks are handbooks for subjects written and compiled by experts in related fields and fulfilling the rules of textbooks. In the field of education, textbooks are closely related to the learning process and curriculum. Textbooks are a means for implementing education and learning. During learning, the teacher can manage learning activities with the help of books. Students or students can participate in learning activities through book means.

Sports Nutrition Science is one of the compulsory subjects in the Physical Education Study Program and Recreation IKIP Budi Utomo Malang. Sports Nutrition Science is the study of the relationship between food management and physical performance that is beneficial for health, fitness, child growth and sports achievement development, especially for sportsmen. The subject of Sports Nutrition Sciences aims to understand the relationship between nutrition, lifestyle and physical performance. Athletes must have appropriate nutrition to obtain optimal health and physical abilities so as to enable them to endure hard physical training and be able to maintain a good appearance during the game.

Interviews with students of the Health and Recreation Physical Education Study Program showed that $80 \%$ of students were less interested in sports nutrition courses. They consider the subject of Sports Nutrition to have nothing to do with the world of sports. This fact makes the lecture in Sports Nutrition less meaningful. Most PJKR students consider Sports Nutrition as a difficult subject. It is not surprising that the results of the Sports Nutrition Science study of the PJKR Study Program students, especially at the IKIP Budi Utomo Malang, are still relatively low. Each semester final examination Minimum Completion Criteria (KKM) is only $45 \%$ to $55 \%$.

\section{METHODS}

The development of this Sports Nutrition Science teaching book refers to the 4D model developed by Thiagarajan, et al. (1974) which consisted of 4 stages, namely Define, Design, Development, and Disseminate, which were modified to be adapted to this study.

\subsection{Define Stage}

At this define stage, conduct an instructional needs analysis needed for the development of textbooks which includes steps: (1) Analyzing basic competencies in Sports Nutrition Science courses, (2) Identifying learning problems, and (3) Identifying weaknesses and 
shortcomings of textbooks Sports Nutrition.

\subsection{Design Stage}

The design phase was carried out to produce an initial draft of the Sports Nutrition Science textbook.

\subsection{Stage of Develop}

This development phase aims to revise the initial draft textbook that has been prepared at the design stage. The revision is based on the validation process carried out by material and media experts. After the validation and revision is complete, a development test is carried out which includes individual testing, small groups and Classroom Action Research (CAR).

\subsection{Disseminate stage}

In this desiminate stage, dissemination of textbooks to be used in lectures on Sports Nutrition, especially for Health Physical Education Study Program and Recreation IKIP Budi Utomo Malang.

\subsection{Feasibility Sheet Data Analysis}

Descriptive statistical analysis was used to process data obtained from student validation sheets and assessment questionnaires. Data will be converted in percentage form with the following formula:

$$
\mathrm{P}=\frac{x}{x i} \times 100 \%
$$

Information:

$\mathrm{P}$ = Percentage of each criterion

$\mathrm{x}=$ Score for each criterion

xi $=$ Maximum score for each criterion

Table 1. Criteria for Feasibility of Textbooks

\begin{tabular}{cl}
\hline Skala (\%) & \multicolumn{1}{c}{ Eligibility Criteria } \\
\hline $85-100$ & worthy of a very good predicate \\
\hline $65-84$ & worthy of a good predicate \\
\hline $45-64$ & worthy with enough predicates \\
\hline $0-44$ & worthy with enough predicates \\
\hline
\end{tabular}

\section{RESULTS AND DISCUSSIONS}

This textbook is validated by material and media experts. The results of the assessment of each validator are calculated and made in the form of percentages.

Table 1. Results of Material Expert Validation

\begin{tabular}{llc}
\hline No & \multicolumn{1}{c}{ Assessment Aspect } & Score \\
\hline 1. & $\begin{array}{l}\text { The material developed has relevance to CPL and has the } \\
\text { final ability to be achieved }\end{array}$ & 4 \\
\hline 2. & $\begin{array}{l}\text { The material developed is consistent or steady in accordance } \\
\text { with the abilities to be achieved }\end{array}$ & 4 \\
\hline 3. & The material developed is adequate so that students can & 4 \\
& master the final abilities to be achieved & 3 \\
\hline 4. & $\begin{array}{l}\text { The material developed includes the types of material in the } \\
\text { form of facts, concepts, principles, and procedures }\end{array}$ & 3 \\
\hline 5. & Presentation of the right material makes it easier for students to \\
& $\begin{array}{l}\text { master the learning material so they can master the final } \\
\text { abilities to be achieved }\end{array}$
\end{tabular}

\begin{tabular}{cc}
\hline $\begin{array}{l}\text { The example given can help students to understand the } \\
\text { material }\end{array}$ & 3 \\
\hline Total Score & 22 \\
\hline Average Score & 3,6 \\
\hline Feasibility Percentage & 91,6 \\
\hline
\end{tabular}

Table 2. Results of Media Expert Validation

\begin{tabular}{llc}
\hline No & Assessment Aspect & Score \\
\hline I. Display Aspects & \\
\hline 1. & $\begin{array}{l}\text { The cover design is made attractive to attract students' } \\
\text { reading interest }\end{array}$ & 4 \\
\hline 2. & Desain of book consistently on every page & 3 \\
\hline 3. & Book design is consistent on every page & 4 \\
\hline 4. & The font size chosen makes it easy for students to read & 3 \\
\hline 5. & $\begin{array}{l}\text { The layout of pictures and texts is regular and harmonious so } \\
\text { that it attracts students' reading interest and is comfortable to } \\
\text { read }\end{array}$ & 3 \\
\end{tabular}

\begin{tabular}{llc}
\hline II. Presentation Aspect & \\
\hline 6. & $\begin{array}{l}\text { Presentation of material in each chapter begins with an } \\
\text { advance organizer }\end{array}$ & 3 \\
\hline 7. & $\begin{array}{l}\text { The contents of the book are presented in a coherent manner } \\
\text { (introduction of material, main material, examples of questions } \\
\text { and exercises) }\end{array}$ & 4 \\
\hline 8. & $\begin{array}{l}\text { Material presentation from the first chapter to the last in the } \\
\text { textbook is continuous and coherent. }\end{array}$ \\
\hline 9. & $\begin{array}{l}\text { Textbooks contain the final achievements of lectures, } \\
\text { competencies, and indicators to be achieved in each teaching } \\
\text { book chapter so that students understand the direction of } \\
\text { learning well. }\end{array}$ \\
\hline 10. & $\begin{array}{l}\text { Textbooks contain graphic elements such as tables, images, } \\
\text { or relevant illustrations to make it easier for users to } \\
\text { understand the material }\end{array}$ \\
\hline \multicolumn{1}{c}{ Total Score } \\
\hline \multicolumn{1}{c}{ Average Score } \\
\hline
\end{tabular}

The assessment results indicate that the assessment of the feasibility of Sports Nutrition Science teaching books by material experts is "very feasible" and the feasibility assessment of Sports Nutrition Science teaching books by media experts is "feasible". In addition to assessments in the form of numbers, material experts and the media provide several suggestions as a reference for the revision of textbooks. Suggestions/comments from Media Expert as in the following table 3.

Table 3. Advice/Comentar from Media Experts

\begin{tabular}{cll}
\hline No. & \multicolumn{1}{c}{ Error Type } & \multicolumn{1}{c}{ Suggestion } \\
\hline 1. & Revised textbook cover design & $\begin{array}{l}\text { The cover design of the textbook is } \\
\text { improved }\end{array}$ \\
\hline 2. & $\begin{array}{l}\text { There is no IKIP Budi Utomo } \\
\text { logo and Kemenristekdikti }\end{array}$ & $\begin{array}{l}\text { Added the logo of IKIP Budi Utomo } \\
\text { and Kemenristekdikti }\end{array}$ \\
\hline 3. & The foreign word letters are & The foreign word letters are tilted \\
& tilted & \\
\hline 4. & There are no pages per chapter & Added pages per chapter \\
\hline 5. & The page does not yet exist & Added page \\
\hline 6. & There are no training questions & Coupled with practice questions \\
\hline
\end{tabular}




\section{CONCLUSION}

Based on the results of the study it can be concluded that the Sports Nutrition Science textbook was declared fit for use as a sports Nutrition Science textbook by material and media experts.

\section{REFERENCES}

Adalikwu, S. A., dan I.T. Iorkpilgh. (2013). The Influence of Instructional Materials on Academic Performance of Senior Secondary School Students in Chemistry in Cross River State. Global Journal of Educational Research. 20 (1).

Arikunto, S. (1993). Prosedur Penelitian Suatu Pendekatan Praktik. Edisi Revisi. Rhineka Cipta. Jakarta.

Arikunto, S. (2008). Dasar-dasar Evaluasi Pendidikan. Bumi Aksara. Jakarta.

Departemen Pendidikan Nasional. 2008. Peraturan Nomor 2 Tahun 2008 Tentang Buku. http://mediainfo.sourceforge.net/. Diakses tanggal 2 Januari 2013.

Direktorat Jenderal Pendidikan Tinggi. 2009. Pedoman Operasional Penilaian Angka Kredit Kenaikan Jabatan Fungsional Dosen ke Lektor Kepala dan Guru Besar. Jakarta: Kemendiknas.

Muslich, M. (2010). Text Book Writing: Dasar-dasar Pemahaman, Penulisan, dan Pemakaian Buku Teks. Ar-Ruzz Media. Jogjakarta.

Thiagarajan, S., Semmel, D.S., and Semmel, M.I. (1974). Instructional Development for Training Teachers of Exceptional Children. National Center for Improvement of Educational. Washington.

Thiagarajan. (1974). Instructional Development for Training Teachers of Exceptional Children. University of Minnesota. New York-USA.

Prastowo, A. (2012). Panduan Kreatif Membuat Bahan Ajar Inovatif. Diva Press. Jogjakarta.

Sugiono. (2010). Metode Penelitian Kuantitatif Kualitatif dan $R \& D$.

Alfabeta. Bandung.

Winarno, M. E. (2011). Metodologi Penelitian dalam Pendidikan Jasmani. Media Cakrawala Utama Press. Malang.

Widoyoko, Eko Putro. (2013). Evaluasi Program Pembelajaran: Panduan Praktis bagi Pendidik dan Calon Pendidik. Pustaka Pelajar. Yogyakarta. 